\title{
Meta-Analysis of Computational Thinking Studies in Science Education: Descriptive Statistics*
}

\author{
Gülbin KIYICI $^{* *} \quad$ Havva YAMAK ${ }^{* * *}$
}

\begin{abstract}
This study aims is to examine the studies on computational thinking in the field of science education descriptive analysis with a holistic approach. Primary studies were determined according to compliance with inclusion and exclusion criteria through document review and national and international database review. The studies included in the scope of the research were evaluated according to the keywords they used, type of publication, year, the language of publication, research methods, sample characteristics, the subject area, and applications covered, and the characteristics of data collection tools used. Findings from 32 primary studies were analyzed under 9 sub-titles. Keywords, which have an important place in the findings, were visualized with word cloud in accordance with the nature of the data. Findings from 32 primary studies were analyzed under 9 sub-titles. Keywords, which have an important place in the findings, were visualized with word cloud in accordance with the nature of the data. According to the determination in the related literature review, researches to develop computational thinking focus on Computer Education and Instructional Technologies, and mathematics. The findings of this research reveal that it is a necessity to use science fields, which are very suitable for developing computational thinking, and to make the necessary changes in the curriculum.
\end{abstract}

Keywords: Meta-analysis, Science Education, computational thinking, descriptive analysis

\footnotetext{
${ }^{*}$ Ethics committee approval for this study was obtained from Gazi University Measurement and Evaluation Ethics Sub-Study Group, dated 01.12.2020 and numbered 12.

** Orcid ID: https://orcid.org/0000-0002-5402-0117, Lect., Manisa Celal Bayar University, Turkey, gulbin.kiyici@gmail.com

*** Orcid ID: https://orcid.org/0000-0002-1666-0746, Prof. Dr., Gazi University, Turkey, havva@gazi.edu.tr

Kıyıcl, G., \& Yamak, H. (2021). Meta-Analysis of Computational Thinking Studies in Science Education: Descriptive Statistics. Sakarya University Journal of Education, 11(3), 526-544. doi: https://doi.org/10.19126/suje.975108
} 


\section{INTRODUCTION}

The basic elements of computational thinking are effective in helping learners reach their goals at the end of the education process and develop thinking systems to make sense of disciplines such as mathematics, science, and language (Grover \& Pea, 2013). An individual with computational thinking skills does not focus on solving the problem, rather, he/she tries to analyze it, collect data about it, and divide it into sub-steps. The aim is not to solve the problem but to understand how to solve the problem and similar problems while determining the steps that make up computational thinking (Vaidyanathan, 2016).

The Science Curriculum, developed on the basis of the General Objectives and Basic Principles of Turkish National Education specified in the second article of the Basic Law of National Education, includes "ensuring that students acquire mathematical competencies" as one of the objectives. Mathematical competence is defined in the science curriculum as follows: "To develop and use mathematical thinking style to solve a series of problems encountered in daily life" (MEB, 2018). Considering the concept of mathematical competence specified in the curriculum, it refers to computational thinking, which is a basic skill not only for computer users but for everyone.

In 2020, the General Directorate of Teacher Training of the Ministry of National Education prepared a resource on the theoretical foundations of computational thinking. The resource emphasizes that computational thinking does not only consist of technological and digital skills but is a whole consisting of the processes performed by each individual in the process of accessing information (Gülbahar et al., 2020).

Computational thinking is the thought processes involved in formulating problems without the need for programming skills (Clark, 2015; Denning, 2017). Improving computational thinking skills contribute to the development of 21st-century skills such as problem-solving, logical reasoning, and analytical thinking(Hunt \& Riley, 2014). The most important reason for the emergence of STEM education, which is one of the most important paradigms in today's world, is the necessity of providing higher-order thinking skills called 21st-century skills for individuals who will be a part of the era of Globalization, Industry 4.0, and Education 4.0. To keep up with global developments, importance should be attached to "Industry 4.0" technologies, which include technologies such as robots, simulation, system integration, cyber security, and augmented reality (Kızlay, Yamak \& Kavak, 2019). To ensure that these skills are acquired and used by students, it is important to provide rich learning experiences, as well as to employ interdisciplinary approaches to teaching science concepts (Canbazoğlu Bilici, Küpeli \& Guzey, 2021). Indeed, for the science course, an approach should be adopted, making it possible to raise individuals who can access the information they need or gain knowledge as a result of experience and who have problem-solving skills (AAAS, 1990; MEB, 2018; NRC, 2000). The development and internalization of computational thinking skills in a computer-free environment can be supported by science learning, through learning processes compatible with the nature of learners. 
In the literature, many studies are investigating the relationship between science education and computational thinking. The results of a study introducing a learning content that includes biological evolution learning coupled with computational thinking found that there was an increase in students' biological evolution knowledge and computational thinking skills, and the increase was significant with medium to large effect sizes (Christensen, 2020). Given the benefits of incorporating computational thinking into disciplines such as physics, the effectiveness of the systematic design and implementation of a computational thinking-based science learning setting has been investigated. Experimental studies have shown that individuals in the experimental group achieve better learning outcomes in science and computational thinking, and create more accurate conceptual and computational models (Basu, 2016; Weese, 2013). In the literature, many studies on computational thinking using STEM, modeling, coding, robotics, and flipped learning methods have reported not only positive but also negative or positive-negative relationships between computational thinking and learning. (Akşit, 2018; Basu, 2016; Lei et al., 2020; Ortiz, 2018; Strawhacker, 2020; Weese, 2013)

This situation, which applies to many fields, has revealed the need for meta-analysis studies due to the need for statistical synthesis and generalization of research on a subject (Glass, 1976; Lipsey \& Wilson, 2001). A meta-analysis study was planned to provide an overall picture of research on computational thinking in science education and to test the variables governing the relationship between science education and computational thinking.

In the literature, where the stages of the meta-analysis process are expressed differently (APA, 2020; Rosenthal \& DiMatteo, 2012; Sánchez-Meca \& Marín-Martínez, 2010), the stages of literature review and coding of data of primary research draw attention.

\section{Purpose}

This study aimed to descriptively analyze the national and international studies focused on computational thinking in science education and thus to contribute to the development of the relevant field. Primary studies were surveyed considering keywords, publication type, publication language, research methods, sample characteristics, subject areas, and practice-related issues.

To determine the studies to be included in the meta-analysis, Higher Education Institution thesis catalog, Ulakbim, ProQuest Digital Dissertations, Proquest EBSCOHOST, ERIC, ScienceDirect, Web of Science, Taylor\&Franchis Online, Scopus, and JSTOR databases were screened according to the inclusion and exclusion criteria. This study is expected to give an idea about which variables should be taken into account or controlled to the researchers working to integrate computational thinking skills into science education, as well as to help to identify the gaps in the relevant literature.

\section{Research Problem}

Which keywords, languages and types, research methods, patterns, and models were used, and which subject areas and practices were covered in research on computational thinking skills in science education? 


\section{METHOD}

Meta-analysis is a statistical method that provides a holistic approach to research in a specific field and helps predict the effect size of research in the population (Arthur, Bennett, and Huffcett 2011; Ellis 2010). On the other hand, the field of statistics is divided into two in terms of its subjects: descriptive statistics and inferential statistics (Yücel 2013). This study includes the stages of "literature review," "coding the data of primary research," and "descriptive analysis of data" of the meta-analysis method, which is one of the quantitative research methods. Primary research is used for studies included in this meta-analysis according to inclusion and exclusion criteria.

\section{Data collection}

Ethics committee approval for this study was obtained from Gazi University Measurement and Evaluation Ethics Sub-Study Group, dated 01.12.2020 and numbered 12. Scientific articles, master's theses, and doctoral theses on computational thinking in science education are the primary research, namely the data source, of this study.

While scanning the sources in the Turkish language in the literature review process, the keywords "science education," "science teaching," "science learning," "STEM," "computational thinking", "machine thinking", and "informational thinking" (their equivalents in Turkish) were used. For sources in the English language, the keywords "science education", "science teaching", "science learning", "STEM" and "computational thinking" were used. The resulting studies were then taken into account according to the following inclusion and exclusion criteria:

\section{Inclusion Criteria}

1. Including practices or variables related to science education,

2. Being published between 2006 and 2020 (since Jeannette Wing's 2006 paper named "Computational Thinking" (Wing 2006) is accepted as the leading publication on the subject),

3. Including computational thinking skills as the dependent variable,

4. Master's and doctoral theses (published or unpublished), papers published in academic (peer-reviewed) journals, congress and symposium papers,

5. Experimental or quasi-experimental studies,

6. Studies containing the necessary data to calculate the effect size,

7. Being published in Turkish or English language,

\section{Exclusion Criteria}

1. Articles published in non-peer-reviewed journals,

2. If an author published the same data both in his/her thesis and in an article, the author's thesis was excluded 
3. Studies that do not report the effect size or statistical data necessary to calculate the effect size,

4. Studies that do not meet the inclusion criteria.

The database scanning process carried out in line with the criteria is shown in Figure-1. Out of the total 112 studies identified as a result of keyword search, 59 were excluded because they were qualitative research, and four were excluded because they reported qualitative computational thinking data (although they used the mixed-methods research design). Furthermore, out of the remaining 49 studies, four were excluded because they were meta-analysis studies, one because it was a scale development study, five because they were thesis-article studies, and five because they did not report the statistical data necessary to calculate the effect size.

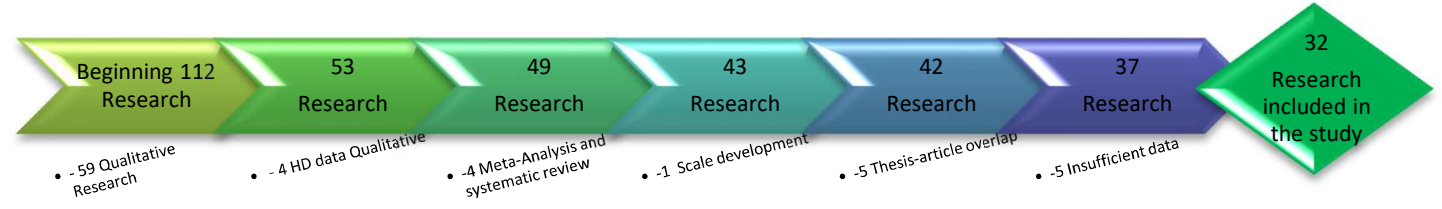

Figure 1. Database scanning process

\section{Coding Method}

The data collection tool of a meta-analysis study is the coding page (Üstün, 2012). At the beginning of this research, the coding page was designed by examining the studies focused on computational thinking in science education. Using the coding page revised in line with the feedback from the field experts, the primary research data for descriptive statistics were prepared.

\section{Data Analysis}

The primary research data were examined in terms of the variables specified in the coding page and were then analyzed descriptively. Descriptive analysis aims to use numbers and graphics to summarize and condense large volumes of data, in other words, to reduce the volume of data and increase its usability (Gürsakal \& Oğuzlar, 2015).

\section{FINDINGS}

The studies included in this meta-analysis were examined according to their keywords, publication type, publication year, publication language, research methods, sample characteristics, subject areas, practices, and the characteristics of the scale used. 


\section{Keywords Used in the Research on Computational Thinking in Science Education}

The keywords used in the primary studies examined within the scope of the research are visualized with word clouds in Figure-2 and Figure-3. Words with higher frequencies are indicated in bigger font sizes in the word cloud. Expectedly, the keywords of the studies carried out in different fields varied.

In Turkish studies, the keywords "informational thinking" ( $\mathrm{f}=3$ ) and "machine thinking" $(\mathrm{f}=2$ ) as the Turkish equivalent of "computational thinking", as well as "scientific process skill" ( $\mathrm{f}=1$ ), "scientific success" ( $\mathrm{f}=1$ )were used, and other keywords were used in only one study per each.

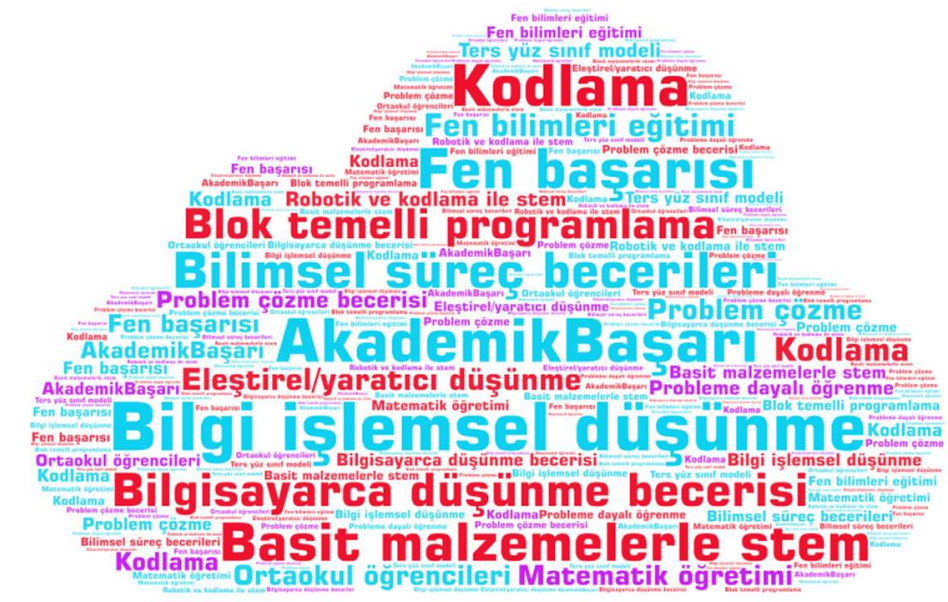

Figure 2. Keywords of Turkish research

Similar to the Turkish studies, the keywords of the English papers examined within this study also varied. The most frequent keywords in English papers were computational thinking ( $\mathrm{f}=18)$, STEM ( $\mathrm{f}=05)$, science education ( $\mathrm{f}=4$ ), and Assessment, Robotics Science learning Self-efficacy ( $\mathrm{f}=3$ ). Out of the remaining English keywords, five were used in two studies and 67 in only one study.

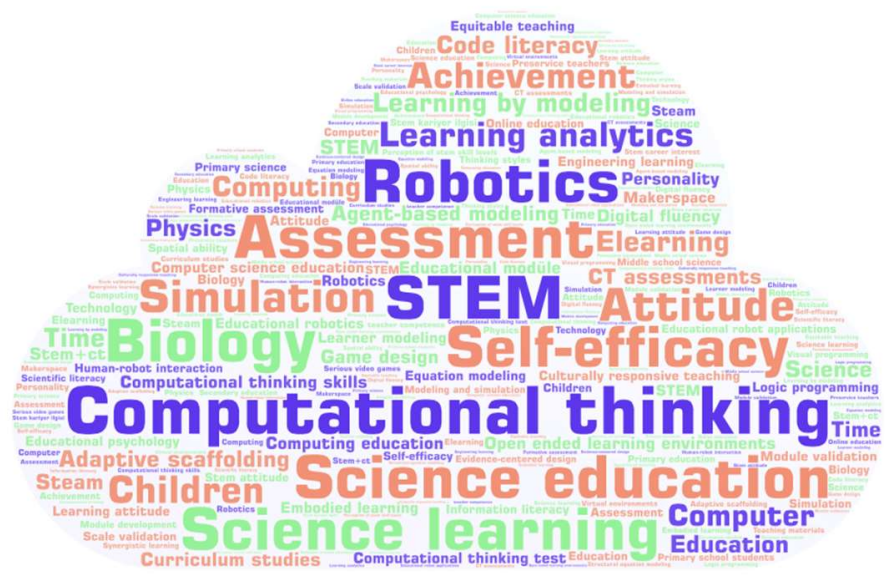

Figure 3. Keywords of English research 


\section{Publication Types of the Research on Computational Thinking in Science Education}

When the national and international studies on computational thinking in science education carried out between 2006 and 2021 (May) were examined, it was found out that $69 \%$ of them were articles in peer-reviewed academic journals, $16 \%$ doctoral theses, $6 \%$ master's theses, and $9 \%$ congress papers.

Table 1

Publication Type in Computational Thinking Research in Science Education

\begin{tabular}{lll}
\hline & Frequency & $\%$ \\
\hline Publication Type & & 69 \\
Master Thesis & 22 & 6 \\
Ph.D. Thesis & 2 & 16 \\
Congress Notice & 5 & 9 \\
\hline
\end{tabular}

\section{Years of the Research on Computational Thinking in Science Education}

The primary research included in this study was reviewed in terms of the practice year, the year when the paper was proposed for publication and the year of publication. $41 \%$ of the studies did not report any information about the practice year, while $47 \%$ did not include any data on the year when the paper was proposed for publication. Also, as can be inferred from Table 2, 85\% of the studies were published after 2018.

Table 2

Year in Computational Thinking Research in Science Education

\begin{tabular}{lllllll}
\hline & \multicolumn{2}{l}{ Year of application } & \multicolumn{2}{l}{$\begin{array}{l}\text { Year proposed } \\
\text { publication }\end{array}$} & $\begin{array}{l}\text { for } \\
\text { Published Year }\end{array}$ \\
& Frequency & $\%$ & Frequency & $\%$ & Frequency & $\%$ \\
\hline Unspecified & 13 & 41 & 15 & 47 & 0 & 0 \\
2021 & 0 & 0 & 0 & 0 & 3 & 9 \\
2020 & 1 & 3 & 8 & 25 & 12 & 38 \\
2019 & 5 & 16 & 4 & 13 & 4 & 13 \\
2018 & 4 & 13 & 1 & 3 & 8 & 25 \\
2017 & 3 & 9 & 1 & 3 & 3 & 9 \\
\hline
\end{tabular}




\begin{tabular}{lllllll}
\hline 2016 & 3 & 9 & 3 & 9 & 0 & 0 \\
2015 & 2 & 6 & 15 & 0 & 2 & 6 \\
2014 & 1 & 3 & 0 & 0 & 0 & 0 \\
\hline
\end{tabular}

\section{Language and Country of the Research on Computational Thinking in Science Education}

Table 3 shows that $16 \%$ and $84 \%$ of the studies were published in Turkish and English, respectively. Also, as can be inferred from Table 3, of the studies, 34\% carried out practices in Turkey, 38\% in the USA, 6\% in Indonesia, 6\% in Greece, 3\% in Malaysia, 3\% in China, 3\% in Canada, and 3\% in Spain.

Table 3

Published Language and Country of Application in Computational Thinking Research in Science Education

\begin{tabular}{lll}
\hline Publication Language & Frequency & $\%$ \\
\hline Turkish & 5 & 16 \\
The English & 27 & 84 \\
\hline Country of application & & \\
\hline Unspecified & 1 & 3 \\
Turkey & 11 & 38 \\
USA & 12 & 6 \\
Indonesia & 2 & 6 \\
Greece & 2 & 3 \\
Malaysia & 1 & 3 \\
Chinese & 1 & 3 \\
Canada & 1 & 3 \\
Spain & 1 & \\
\hline
\end{tabular}

\section{Methods Used in the Research on Computational Thinking in Science Education:}

Under this heading, it was also investigated whether and what percentage of the studies conducted a pilot study. As a result, it was seen that $41 \%$ of the studies conducted a pilot study while 59\% did not (Table 4). On the other hand, considering the research method used in the papers, 38\% used the quantitative research method, while $63 \%$ used the mixed-methods design (but collected the data on computational thinking using quantitative methods). In addition, it can be inferred from Table 4 that $56 \%$ of the studies used the quasi-experimental design, $19 \%$ the weak experimental design, and $6 \%$ the experimental design. 
Table 4

Method in Computational Thinking Research in Science Education

\begin{tabular}{lll}
\hline Has a pilot study been conducted in the research? & Frequency & $\%$ \\
\hline Yes & 13 & 41 \\
No & 19 & 59 \\
\hline Research Method & & \\
\hline Quantitative Method & 12 & 38 \\
Mixed-Method & 20 & 63 \\
\hline The Pattern of the Research & 1 & 3 \\
Unspecified & 2 & 6 \\
Real Experimental Pattern & 18 & 56 \\
Semi-Experimental Pattern & 6 & 19 \\
Weak Experimental Pattern & 5 & 16 \\
Non-Experimental Pattern & & 0 \\
\hline Research Model & 0 & 38 \\
\hline Unspecified & 12 & 3 \\
Pretest/posttest model with experimental-control group & 1 & 34 \\
The Post-test model with experimental-control group & 1 & 9 \\
Single group pretest/posttest model & 11 & 16 \\
Single group posttest model & 3 & \\
Relational screening model & 5 & \\
\hline
\end{tabular}

\section{Samples Used in the Research on Computational Thinking in Science Education}

Samples of the primary research were evaluated in terms of sampling method, school level, demographic characteristics, and school types. $9 \%$ of the studies do not report any data on their sampling methods. As can be inferred from

Table 5, a majority of the studies (47\%) used convenience sampling, $16 \%$ purposive sampling, and 19\% simple random sampling. 53\% enrolled 5th to 8th graders as their sample, $22 \%$ th to 12 th graders, and $16 \%$ undergraduate students.

Table 5 demonstrates the relevant frequency values. Also, $72 \%$ were carried out in urban areas, $16 \%$ in rural areas and $9 \%$ do not report any information about the demographic characteristics of their sample.

Table 5

Sampling of Computational Thinking Research in Science Education

\begin{tabular}{lll}
\hline Sampling Method & Frequency & $\%$ \\
\hline Unspecified & 3 & 9 \\
Simple Random Sampling & 6 & 19 \\
Stratified Random Sampling & 0 & 0 \\
\hline
\end{tabular}




\begin{tabular}{lll}
\hline Cluster Random Sampling & 1 & 3 \\
Two-stage Random Sampling & 1 & 3 \\
Systematic Non-Random Sampling & 1 & 3 \\
Convenient Non-Random Sampling & 15 & 47 \\
Purposeful Non-Random Sampling & 5 & 16 \\
\hline Sample Group (School Level) & & 0 \\
\hline Unspecified & 0 & 0 \\
1-4. Class & 0 & 53 \\
5-8. Class & 17 & 22 \\
9-12. Class & 7 & 16 \\
License & 5 & 0 \\
Graduate & 0 & 6 \\
Teachers & 2 & 3 \\
Mixed & 1 & 9 \\
Sample Demographic Structure & & 72 \\
\hline Unspecified & 3 & 16 \\
Urban & 23 & 3 \\
Rural & 5 & \\
Mixed & 1 & 9 \\
\hline School Type & & 6 \\
\hline Unspecified & 3 & 69 \\
Private school & 2 & 9 \\
State school & 22 & 6 \\
Summer school & 3 & \\
Mixed & 2 & \\
\hline
\end{tabular}

Finally, considering the characteristics of the samples, $69 \%$ of the studies were carried out in public schools and $6 \%$ in private schools. On the other hand, $9 \%$ do not report any information about the school type.

\section{Subject Areas of the Research on Computational Thinking in Science Education}

Table 6shows that of the studies on computational thinking in science education, $47 \%$ were carried out in relation to STEM, $16 \%$ in relation to science courses, and $16 \%$ in relation to physics courses. On the other hand, only $3 \%$ of the studies on computational thinking were carried out in relation to chemistry courses, which is a noteworthy finding.

Table 6

The Subject Area of Computational Thinking Research in Science Education

\begin{tabular}{lll}
\hline Subject Area of Practice in Research & Frequency & $\%$ \\
\hline Unspecified & 2 & 6 \\
STEM & 15 & 47 \\
Science & 5 & 16 \\
\hline
\end{tabular}




\begin{tabular}{lll}
\hline Physical & 5 & 16 \\
Biology & 3 & 9 \\
Chemical & 1 & 3 \\
Astronomy & 1 & 3 \\
\hline
\end{tabular}

\section{Practices Used in the Research on Computational Thinking in Science Education:}

\section{Duration of Practice}

Since it is important in an experimental or quasi-experimental study how often practice is performed and how long it takes, it is also important how detailed the duration is given. According to Table 7, where the findings related to the practices are presented, $34 \%$ of the studies specified durations of practice as minutes, $28 \%$ as weeks, and $38 \%$ do not report any information about the duration of practice. Of those which specified durations of practice as weeks, $19 \%$ stated that their practices took 1 to 3 weeks, $27 \% 4$ to 7 weeks, and $13 \%$ more than 12 weeks.

\section{The person carrying out the practice}

According to Table 7, the practice was carried out by the teacher in $53 \%$ of the studies and by the researcher in $22 \%$ of the studies. On the other hand, $25 \%$ of the studies do not report any information about the person who carried out the practice.

\section{The instrument used for the practice}

In $56 \%$ of the studies, computers were used for the practice, coding in $53 \%$, robotics in $28 \%$, algorithms in $6 \%$, and the flipped learning method in $3 \%$.

Table 7

Findings on Application in Computational Thinking Research in Science Education

\begin{tabular}{lll}
\hline & Frequency & $\%$ \\
Implementation Time unit & & \\
\hline Unspecified & 12 & 38 \\
Those who specify the application time in & 11 & 34 \\
Those who specify the application period as & 9 & 28 \\
\hline Implementation Period (Week) & & \\
\hline Unspecified & 12 & 38 \\
$1-3$ & 6 & 19 \\
$4-7$ & 8 & 25 \\
$8-11$ & 2 & 6 \\
12 and above & 4 & 13 \\
\hline Who is the practitioner? & & \\
\hline Unspecified & 8 & 25
\end{tabular}




\begin{tabular}{lll} 
Experiment Control Investigator & 7 & 22 \\
Experiment Control Teacher & 17 & 53 \\
\hline Computer Used? & 6 & \\
\hline Unspecified & 18 & 19 \\
Yee & 8 & 56 \\
No & & 25 \\
\hline Is Coding Used? & 6 & \\
\hline Unspecified & 17 & 19 \\
Yeah & 9 & 53 \\
No & & 28 \\
\hline Is Robotics Used? & 6 & \\
\hline Unspecified & 9 & 19 \\
Yeah & 17 & 28 \\
No & & 53 \\
\hline Is algorithm used? & 6 & \\
\hline Unspecified & 2 & 19 \\
Yeah & 24 & 6 \\
No & & 75 \\
\hline Is the Flipped Class Application Used? & 6 & 19 \\
\hline Unspecified & 1 & 3 \\
Yeah & 25 & 78 \\
No & & 25 \\
\hline Applied process & 8 & 25 \\
\hline Activity Enhanced & 8 & 9 \\
Information and Communication Technologies & 5 & \\
STEM apps used & 3 & 25 \\
Method comparison made & 8 & \\
No action was taken & & \\
\hline & 85 & \\
\hline
\end{tabular}

Table 7 shows that activities to improve computational thinking skills were developed in $25 \%$ of the studies. $25 \%$ of the studies carried out practices that aimed to develop computational thinking skills using information and communication technologies, while $16 \%$ used practices that aimed to develop computational thinking skills with STEM practices. On the other hand, $9 \%$ of the studies compared methods of the two groups.

\section{Scales Used in the Research on Computational Thinking in Science Education}

According to Tablo 8, half of the studies used Likert-type scales, and 25\% used achievement tests. On the other hand, $6 \%$ of the studies do not report any information about the scale used. On the other hand, $6 \%$ of the studies do not report any information about the scale used. The scarcity of studies using the "Q sort"(Block 1964; Evelina and Nadia 2014) data collection procedure (open-ended questions), which is recommended in the literature to be used for the measurement of personality traits, is also striking. Regarding the developers of the scale used, the scale was developed by the researcher in 
$47 \%$ of the studies, and the researcher used a previously developed scale in $47 \%$ of the studies. On the other hand, $3 \%$ of the studies do not report any information about the developer of the scale.

Tablo 8

Scale in Computational Thinking Research in Science Education

\begin{tabular}{lll}
\hline & Frequency & $\%$ \\
\hline Type of Scale used & & 6 \\
\hline Unspecified & 2 & 25 \\
Achievement test & 8 & 50 \\
Likert Type & 16 & 6 \\
Rubric & 2 & 9 \\
Q Sort (Open-Ended Questions) & 3 & 3 \\
Osgood's Semantic Discrimination Scale & 1 & 3 \\
\hline Developer of the Scale & & 47 \\
\hline Unspecified & 1 & 47 \\
Pre-existing scale & 15 & 3 \\
Developed by the researcher & 15 & \\
Adapted scale & 1 & \\
\hline
\end{tabular}

\section{CONCLUSION, DISCUSSION, AND RECOMMENDATIONS}

This study aimed to descriptively analyze the studies on computational thinking in the field of science education with a holistic approach. Primary research identified in national and international databases through document review were evaluated according to keywords, publication type, publication year, publication language, research methods, sample characteristics, subject area and practices, and characteristics of data collection tools. Findings from 32 primary studies were analyzed under nine subheadings.

As regards the year when the studies were conducted, $75 \%$ of the studies were conducted after 2018, and 38\% of all the studies were conducted in 2020 (Table 2). In the literature review phase, it was found that computational thinking skills were mostly studied in relation to computer and instructional technologies and mathematics. It was also observed that the number of studies on computational thinking in science education 
gradually increased after Wing (2006), which is accepted as the pioneering research in this field. "Computational thinking" studied in this study refers to thinking like a computer scientist, which includes much more than being able to program a computer (Wing, 2006). At the core of computational thinking is the mental execution of the programmed, along with programming (Bocconi et al., 2016). In this respect, considering that computational thinking is a thinking process and problem-solving is a part of this process, it should not be ignored that science-related subjects can contribute to computational thinking skills.

The fact that although $16 \%$ of all primary studies were published in Turkish, $34 \%$ of them were conducted in Turkey reveals that studies on the development of computational thinking skills in science education are given importance in our country.

If a study is not planned in accordance with all the features of the experimental design, internal and external validity problems may arise, as a result of which findings may become controversial (Yllmaz \& Tuncer, 2020). This risk can be eliminated by conducting a pilot study before the intended study. However, it is seen that $51 \%$ of the studies examined within the scope of this research did not carry out a pilot study. To make permanent and correct contributions to the literature, pilot studies should be conducted in research.

Once a researcher has identified a research problem related to a topic of interest, he/she must decide on the method to solve this problem. This method should be suitable for the characteristics of the researcher, the purpose of the research, and the nature of the problem (Creswell \& Creswell, 2018). When primary studies are examined in this context, it is seen that $37 \%$ of them used the quantitative method. However, considering the fact that mixed-methods research, in which qualitative data and quantitative data support each other, provides more quality data, the importance of this ratio is better understood. Determining a sample suitable for the research method and research problem is important to reach the correct results because the wrong sample selection causes the results to lose their validity. The fact that only $19 \%$ of the studies included in this meta-analysis determined their samples using the simple random sampling method may raise concerns about the validity of findings of research on computational thinking in science education. On the other hand, another threat to the validity of the results is that $53 \%$ of the studies enrolled 5 th to 8 th graders as their samples. Computational thinking is included as a unit in the science curriculum of the fifth and sixth grades published in 2018 (MEB, 2018). It should be noted that computational thinking does not refer to a thinking process related to only mathematics or computer science. Therefore, computational thinking should be included as an objective, not as a subject or unit, in the curricula of all pre-school, primary school, and middle school courses.

Planning future research at other educational levels can eliminate this threat. The same threat is also true for the demographic characteristics of the samples. $72 \%$ of the primary studies were conducted in urban areas. Therefore, it is not possible to generalize their results. 
Considering the subject areas of the studies, mostly STEM applications, physics, and science subjects were preferred in the studies. On the other hand, chemistry, biology, and astronomy also include topics suitable for the development of computational thinking skills. Considering that the interests and learning styles of learners differ, it is necessary to benefit from practices in every field.

There is no rule for the duration of practice in an experimental study, but the duration must be long enough to cause a permanent change in the dependent variable, and it must be ensured that there are no other factors that can manipulate the dependent variable. The meta-analysis studies conducted in the literature have revealed that high, medium and large effect sizes are achieved regardless of the duration of the experimental practice, but if the duration exceeds a certain level, there is a decrease in the effect size (Balemen, 2016; Dağyar and Demirel, 2015; Ural, 2014). Therefore, a pilot study should be conducted to determine the optimum time for the practice, and the duration should be specified in detail in the research report.

It was found that studies on developing computational thinking in science education mostly used computers, coding, robotics, and flipped learning methods (Çakır \& Yaman, 2018; Jaipal-Jamani \& Angeli, 2017; Uşengül \& Bahçeci, 2020). Today, it is seen that materials that support the development of computational thinking skills are frequently used in flipped learning practices (Çakır \& Yaman, 2018; Çukurbaşı \& Kıyıcı, 2018; Hamutoglu, 2021; Özüdoğru, 2018; Uşengül, 2019). However, it should not be forgotten that computational thinking skills also include algorithmic thinking. Only 6\% of the studies used algorithm activities. Research aimed at developing computational thinking skills should also involve algorithm and coding activities and practices that do not require computers. Considering the scales used in primary studies, it was seen that they were developed in relation to the practice carried out in the study. Failure to use a reliable and generalizable scale also risks the reliability and validity of research results.

Future research on the development of computational thinking skills in science education should take into account all the sub-branches of the field, determine the optimum duration for the practice through pilot studies, and determine the research method-pattern-model according to the research problem.

\section{References}

AAAS (1990). American Association for the Advancement of Science. Science for All Americans: Education for a changing future. http://www.project2061.org/publications/sfaa/online/sfaatoc.htm adresinden erişilmiştir.

Aksit, O. (2018). Enhancing Science Learning through Computational Thinking and Modeling in Middle School Classrooms: A Mixed Methods Study. North Carolina State University. 
APA. (2020). Publication Manual of The American Psychological Association 7th. Washington DC.

Arthur, J., Bennett, W., \& Huffcutt, A. I. (2001). Conducting meta-analysis using SAS. Psychology Press.

Balemen, N. (2016). Proje tabanlı öğrenme yaklaşımının fen eğitimindeki etkililiği: meta analiz çalışması [The effectiveness of the project-based learning approach in science education: meta-analysis study]. (Unpublished Doctoral Dissertation) Gazi University, Ankara.

Basu, S. (2016). Fostering synergistic learning of computational thinking and middle school science in computer-based intelligent learning environments. (Unpublished Dissertation) Vanderbilt University.

Block, J. (1964). The Q-sort method in personality assessment and psychiatric research. The Journal of Nervous and Mental Disease, 136(6), 604-605.

Bocconi, S., Chioccariello, A., Dettori, G., Ferrari, A., \& Engelhardt, K. (2016). Developing computational thinking in compulsory education-Implications for policy and practice (No. JRC104188). Joint Research Centre (Seville site).

Çakir, E., \& Yaman, S. (2018). Ters Yüz Sınıf Modelinin Öğrencilerin Fen Başarısı ve Bilgisayarca Düşünme Becerileri Üzerine Etkisi [The Effect of Flipped Classroom Model on Students' Science Achievement and Computer Thinking Skills]. Gazi University Journal of Gazi Educational Faculty (GUJGEF), 38(1), 75-99.

Canbazoğlu Bilici, S., Küpeli, M. A., \& Guzey, S. S. (2021). Inspired by nature: an engineering design-based biomimicry activity. Science Activities, 58(2), 77-88.

Christensen, D. M. (2020). Learning Biological Evolution Through Computational Thinking (Doctoral dissertation) Temple University.

Clark, D. (2015). Computational and algorithmic thinking, 2011-2015. Canberra, Australia: Australian Mathematics Trust.

Creswell, J. W., \& J. D. Creswell. (2018). Research Design Qualitative, Quantitative, and Mixed Methods Approaches. Los Angles/London/ New Delhi/Singapore/Washington DC/ Melbourne: SAGE.

Çukurbaşi, B., \& Kiyici, M. (2018). Öğretmen adaylarının elektronik portfolyoya yönelik görüşlerinin incelenmesi: Weebly örneği [Examination of pre-service teachers' views on electronic portfolio: The example of Weebly]. İnönü Üniversitesi Eğitim Fakültesi Dergisi, 19(1), 1-14.

Dagyar, M., \& Demirel, M. (2015). Effects of problem-based learning on academic achievement: A meta-analysis study. Egitim ve Bilim, 40(181), 139-174.

Denning, P. J. (2017). Computational thinking in science. American Scientist, 105(1), 13-17.

Ellis, P. D. (2010). The Essential Guide to Effect Sizes. Cambridge University Press.

Evelina, B. C., \& Nadia, B. C. (2014). The Q-sort technique used in identifying the level of methodological skills of the prospective teachers. Procedia-Social and Behavioral Sciences, 128, 60-65.

Glass, G. V. (1976). Primary, secondary, and meta-analysis of research. Educational researcher, 5(10), 3-8. 
Gülbahar, Y., Çakıroğlu, Ü., Kalelioğlu, F., Delen, İ., Yıldız, B., \& Sayın, Z. (2020). Bilgi İşlemsel Düşünme Becerisinin Disiplinlerarası Yaklaşım ile Öğretimi [Teaching Computational Thinking Skills with an Interdisciplinary Approach]. S. Akbıyık ve V. H. Kaya (Ed.). Ankara: MEB ÖYGM.

Gürsakal, N., \& Oğuzlar, A. (2015). No Title. Dora Yayıncllık.

Hamutoglu, N. B. (2021). A Road Map for the COVID-19 Pandemic Process to Ensure Quality of Assurance Active Learning Strategies in Online Learning Environments: How to Plan, Implement, Evaluate, and Improve Learning Activities. In Handbook of Research on Emerging Pedagogies for the Future of Education: Trauma-Informed, Care, and Pandemic Pedagogy (ss. 101-126). IGI Global.

Riley, D. D., \& Hunt, K. A. (2014). Computational thinking for the modern problem solver. CRC press.

Jaipal-Jamani, K., \& Angeli, C. (2017). Effect of robotics on elementary preservice teachers' self-efficacy, science learning, and computational thinking. Journal of Science Education and Technology, 26(2), 175-192.

Kizilay, E., Yamak, H., \& Kavak, N. (2019). Motivation Scale for STEM Fields. Journal of Computer and Education Research, 7(14), 540-557.

Lei, H., Chiu, M. M., Li, F., Wang, X., \& Geng, Y. J. (2020). Computational thinking and academic achievement: A meta-analysis among students. Children and Youth Services Review, 118, 105439.

Lipsey, M. W., \& Wilson, D. (2001). Practical Meta Analysis Overview. Applied Social Research Methods Series.

MEB. (2018). Fen Bilimleri Dersi Öğretim Programı (Illkokul ve Ortaokul 3, 4, 5, 6, 7 ve 8. Siniflar) [Science Curriculum (Primary and Secondary Schools 3, 4, 5, 6, 7 and 8th Grades)]. Ankara.

NRC. (2000). National Research Council. Inquiry and the National Science Education Standards: A Guide for Teaching and Learning. Washington: DC: The National Academies Press.

Ortiz, C. J. (2018).An Experimental Comparison of Student Motivation Between Two Computational Thinking-based Stem Activities: Vex-based Automation and Robotics and a Quadcopter Activity (Doctoral dissertation) Utah State University.

Özüdoğru, M. (2018). The effect of flipped learning on pre-service teachers' achievement and perceptions related to classroom environment. (Unpublished Dissertation) Middle East Technical University.

Rosenthal, R., \& DiMatteo, M. R. (2001). Meta-analysis: Recent developments in quantitative methods for literature reviews. Annual review of psychology, 52(1), 59-82.

Sánchez-Meca, J., \& Marín-Martínez, F. (2010). Meta-analysis in psychological research. International Journal of Psychological Research, 3(1), 150-162.

Strawhacker, A. L. (2020). Biodesign Education in Early Childhood: A Design-Research Study of the Tangible Crispee Technology and Learning Intervention (Doctoral dissertation) Tufts University. 
Ural, G. (2014). Illköğretimde Fen ve Teknoloji Öğretimi Üzerine Türkiye'de Yapılan Araștırmaların Meta Analizi [Meta-Analysis of Researches on Science and Technology Teaching in Primary Education in Turkey] (Unpublished Doctoral Dissertation) Ege University, İzmir.

Uşengül, L., \& Bahçeci, F. (2020). The Effect of Lego Wedo 2.0 Education on Academic Achievement and Attitudes and Computational Thinking Skills of Learners toward Science. World Journal of Education, 10(4), 83-93.

Uşengül, L. (2019). Lego Wedo 2.0 eğitiminin öğrenenlerin fen bilimlerine yönelik akademik başarı ve tutumları ile bilgi işlemsel düşünme becerilerine etkisi [The effect of Lego Wedo 2.0 education on learners' academic achievement and attitudes towards science and computational thinking skills] (Unpublished Masters' Thesis). Firat University, Elazığ.

Üstün, U. (2012). To what extent is problem-based learning effective as compared to traditional teaching in science education? A meta-analysis study. (Unpublished Dissertation) Middle East Technical University.

Weese, J. L. (2017). Bringing computational thinking to $K-12$ and higher education. (Unpublished Dissertation) Kansas State University.

Wing, J. M. (2006). Computational thinking. Communications of the ACM, 49(3), 33-35.

Yilmaz, Ö., \& Tuncer, M. (2020). Deneysel bir araştirmada pilot çalişmanin önemi: dale'in yaşanti konisine göre öğretimin akademik başariya etkisi [The importance of a pilot study in an experimental research: the effect of teaching on academic achievement according to dale's life cone]. Electronic Journal of Education Sciences, 9(17), 89-96. 
Ethics committee approval for this study was obtained from Gazi University Measurement and Evaluation Ethics Sub-Study Group, dated 01.12.2020 and numbered 12.

\section{Statement of Contribution of Researchers to the Article:}

1st author contribution rate: $50 \%$

2nd author contribution rate: $50 \%$

Conflict of Interest Statement:

There is no conflict of interest.

Statement of Financial Support or Acknowledgment:

No financial support was received from any institution for this study. 


\title{
Fen Eğitiminde Hesaplamalı Düşünme Çalışmalarının Meta-Analizi: Betimsel İstatistikler*
}

\section{Gülbin KIYICI**}

\author{
Havva YAMAK ${ }^{* *}$
}

\begin{abstract}
Öz. Bu araştırmanın amacl, fen eğitimi alanında hesaplamalı düşünme üzerine yapılmış çalışmaları bütüncül bir yaklaşımla betimsel olarak incelemektir. Doküman incelemesi yoluyla ulusal ve uluslararası veri tabanları incelenerek dahil edilme ve hariç tutulma kriterlerine uygun olduğu belirlenen birincil araştırmalar, anahtar kelimeler, yayın türü, yıl, yayın dili, araştırma yöntemleri, örneklem özellikleri, konu alanı ve uygulamalar ve veri toplama araçlarının özelliklerine göre değerlendirilmiştir. 32 birincil araștırmadan elde edilen bulgular dokuz alt başlıkta incelenmiştir. Bulgular içinde önemli bir yeri olan anahtar kelimeler verinin doğasına uygun olarak kelime bulutuyla görselleștirilmiștir. Araștırmada hesaplamalı düşünmeyi geliştirmeye yönelik araştırmaların daha çok bilgisayar ve öğretim teknolojileri ve matematik eğitimi alanlarında gerçekleștirildiği tespit edilmiştir. Araştırma sonucunda fen eğitimi alanında yıl, yayın dili, araştırma yöntemleri, örneklem özellikleri, konu alanı ve uygulamalar gibi değişkenlerin odağında gerçekleştirilecek araştırmaların alan yazına katkı sağlayacağı önerilmektedir.
\end{abstract}

Anahtar Kelimeler: Meta-analiz, fen eğitimi, hesaplamalı düşünme, betimsel analiz.

\footnotetext{
${ }^{*}$ Bu çalışma için etik kurul izni 01.12.2020 tarih ve 12 sayılı Gazi Üniversitesi Ölçme ve Değerlendirme Etik Alt Çalışma Grubu'ndan alınmıștır.

** Orcid ID: https://orcid.org/0000-0002-5402-0117, Öğr. Gör., Manisa Celal Bayar Üniversitesi, Türkiye, gulbin.kiyici@gmail.com

*** Orcid ID: https://orcid.org/0000-0002-1666-0746, Prof. Dr., Gazi Üniversitesi, Türkiye, havva@gazi.edu.tr

Kıyıcl, G., \& Yamak, H. (2021). Meta-Analysis of Computational Thinking Studies in Science Education: Descriptive Statistics. Sakarya University Journal of Education, 11(3), 526-544. doi: https://doi.org/10.19126/suje.975108
} 


\section{GİRİş}

Öğrenen bireylerin eğitim süreci sonunda hedefe ulaşmaları bununla birlikte matematik, fen ve dil gibi konuları anlamlandırabilecek düşünme sistemleri oluşturmalarında hesaplamalı düşünmenin temel öğeleri etkili olmaktadır (Grover ve Pea, 2013). Birey hesaplamalı düşünme becerisine sahipse, problemi çözmeye değil onu analiz edip, veri toplayıp alt basamaklarına ayırmaya odaklanır. Amaç problemi çözmek değil hesaplamalı düşünmeyi oluşturan basamakları belirlerken söz konusu problemi ve benzerlerinin nasıl çözüleceğini anlamaktır (Vaidyanathan, 2016).

Milli Eğitim Temel Kanununun 2. maddesinde yer alan Türk Millî Eğitimi'nin Genel Amaçları ve Temel İlkeleri esas alınarak hazırlanan Fen Bilimleri Öğretim Programında öğrenenlere matematiksel yetkinliklerin kazandırılması, hedefler arasında ifade edilmektedir. Matematiksel yetkinliğin fen bilimleri öğretim programında yer alan tanımı "günlük hayatta karşılaşılan bir dizi problemi çözmek için matematiksel düşünme tarzını geliştirme ve uygulama" şeklindedir (MEB, 2018). Programda yer bulan matematiksel yetkinlik kavramı incelenirse, sadece bilgisayarcılar için değil herkes için geçerli temel bir beceri olan hesaplamalı düşünmeyle ilişkisi görülecektir.

Milli Eğitim Bakanlığı Öğretmen Yetiştirme Genel Müdürlüğü'nün 2020 yılında Hesaplamalı düşünmenin kuramsal temellerine ilişkin kaynak hazırlamıştır. Hesaplamalı düşünme ayrıntılı incelendiğinde sadece teknoloji ve dijital becerilerden oluşmadığı, her bireyin bilgiye ulaşma sürecinde gerçekleştirdiği süreçlerden oluşan bir bütün olduğu vurgulanmıştır (Gülbahar vd., 2020).

Hesaplamalı düşünme, programlama becerilerine ihtiyaç duymadan problemlerle uğraşarak, onların formüle edilmesinde yer alan düşünce süreçleridir (Clark 2015; Denning, 2017). Hesaplamalı düşünmeyi geliştirmek, yirmi birinci yüzyıl becerilerinden olan problem çözme, mantıksal akıl yürütme ve analitik düşünme becerilerinin gelişimine de katkı sağlayacaktır (Hunt ve Riley, 2014). Yüz yılımız da dünyadaki en önemli paradigmalardan birisi olan STEM eğitiminin ortaya çıkma sebeplerinin en önemlisi, Küreselleşme, Endüstri 4.0 ve Eğitim 4.0 çağında görev alabilecek bireylere 21 . yy. becerileri olarak adlandırılan üst düzey düşünme becerilerinin kazandırılması gerçeğidir. Küresel değişime ayak uydurabilmek için robotlar, simülasyon, sistem entegrasyonu, siber güvenlik, artırılmış gerçeklik gibi teknolojileri içeren "endüstri 4.0" teknolojilerine önem verilmesi gerekliliği gözden kaçırılmamalıdır (Kızılay, Yamak ve Kavak, 2019). Bu becerilerin kazandırılması ve öğrenciler tarafından anlamlandırılması için öğrenme deneyimleri sağlamak; bunun yanında disiplinler arası yaklaşımlarla fen kavramlarının öğretimine yönelik süreçlerin işe koşulması önemli bir ihtiyaçtır (Canbazoğlu Bilici, Küpeli ve Guzey, 2021). Çünkü fen bilimleri dersi için ihtiyaç duyduğu bilgiye ulaşabilen ya da bilgileri deneyimler sonucun da kazanan ve problem çözme becerisine sahip bireyler yetiştirmeyi mümkün kılan bir yaklaşım benimsenmelidir (AAAS, 1990; MEB, 2018; NRC, 2000). Öğrenenlerin doğasıyla uyumlu öğrenme süreçleriyle, bilgisayarsız ortamda hesaplamalı düşünme becerisinin geliştirilmesi ve içselleştirilmesi fen öğrenme süreciyle desteklenebilir. 
Alan yazında fen eğitimi ile hesaplamalı düşünmenin ilişkisinin araştırıldığı birçok çalışma görülmektedir. Biyolojik evrim ve hesaplamalı düşünmenin doğasını dikkate alan içerik tasarlanan bir araştırmanın sonuçları, evrim bilgisi ve hesaplamalı düşünme bilgisinde artış olup, bu değişimin orta - büyük etki büyüklükleri ile önemli düzeyde olduğunu göstermektedir (Christensen, 2020). Hesaplamalı düşünmenin fizik gibi disiplinlere dahil edilmesinin yararlarının görüldüğü, hesaplamalı düşünme tabanlı bir fen öğrenme ortamının sistematik tasarımı ve uygulaması yaplan deney grubundaki bireylerin daha yüksek bilim ve hesaplamalı düşünme öğrenme kazanımları gösterdiği, daha doğru kavramsal ve hesaplama modelleri oluşturduklarının tespit edildiği deneysel araștırmalarla ortaya konmuștur (Basu, 2016; Weese, 2013). Alan yazında Hesaplamalı düşünmeye ilişkin araştırmalarda STEM, modelleme, kodlama, robotik ve ters yüz sınıf yöntemi uygulamalarının olduğu birçok araştırma, sadece hesaplamalı düşünme ve öğrenmeye ilişkin tamamen olumlu ilişkiler değil olumsuz yada olumlu-olumsuz ilişsileri birlikte barındıran araştırmalar da görülmektedir(Akșit, 2018; Basu, 2016; Lei vd., 2020; Ortiz, 2018; Strawhacker, 2020; Weese, 2013)

Birçok alanda söz konusu olan bu durum bir konu üzerine yapılmış araştırmaların istatistiksel olarak sentezlenmesi ve genellenebilme ihtiyacından dolayı meta-analizi ortaya çıkarmıştır (Glass, 1976; Lipsey ve Wilson, 2001). Fen Eğitimin de hesaplamalı düşünme araştırmalarına yönelik genel bir sonuç elde etmek ve bu ilişkiyi yöneten değişkenleri test etmek için bir meta-analiz çalışması planlanmıştır.

Meta-analiz sürecinin aşamalarının farklı şekilde ifade edildiği alan yazında (APA, 2020; Rosenthal ve DiMatteo, 2012; Sánchez-Meca ve Marín-Martínez, 2010), literatür taraması ve birincil araştırmaların verilerinin kodlanması aşamasına dikkat çekilmektedir.

\section{Amaç}

Bu çalışmada ulusal ve uluslararası alan yazında fen eğitiminde hesaplamalı düşünme odağında yapılan araştırmaları bütüncül bir yaklaşımla betimsel olarak incelenmesi ve bu alanda yapılan araştırmalarının geliştirilmesi amaçlanmıştır. Birincil araştırmalar anahtar kelimeler, yayın türü, yayın dili, araştırma yöntemleri, örneklem özellikleri, konu alanı ve uygulamayla ilgili konular bakımından incelenmiştir.

Araştırmaya dâhil edilecek çalışmaları belirlemek üzere dahil etme kriterleri ve dışlama kriterleri doğrultusunda Yüksek Öğretim Kurumu tez kataloğu, Ulakbim, ProQuest Digital Dissertations, Proquest EBSCOHOST, ERIC, ScienceDirect, Web of Science, Taylor\&Franchis Online, Scopus ve JSTOR veri tabanlarında tarama yapılmıștır. Bu çalışmanın fen eğitimi alanında hesaplamalı düşünme becerisini geliştirmeye yönelik çalışan araştırmacılara hangi değişkenlerin dikkate alınması tada kontrol edilmesi gerektiğiyle ilgili fikir verirken alan yazındaki eksikliklerin anlaşılmasına da yardımı olacağı düşünülmektedir. 


\section{Problem}

Fen eğitiminde hesaplamalı düşünme becerisine yönelik araştırmalar hangi anahtar kelimeleri kullanarak, hangi dilde ve türde; hangi araștırma yöntemi, deseni ve modeline göre, hangi konu alanı ve uygulamaları kapsayacak șekilde yapılmıştır?

\section{YÖNTEM}

Meta-analiz, bir alandaki araştırmalara bütüncül olarak yaklaşmak ve araştırmaların evrendeki etki büyüklüğünü tahmin etmeyi sağlayan istatistiksel bir yöntemdir (Arthur, Bennett ve Huffcett, 2011; Ellis, 2010). Diğer taraftan istatistik alanı betimsel (tasviri) istatistik ve çıkarımsal istatistik olmak üzere, konuları bakımından ikiye ayrılır (Yücel, 2013). Bu çalışma nicel araştırma yöntemlerinden biri olan meta-analiz yönteminin alan yazın taraması ve birincil araştırmaların verilerinin kodlanması aşamasından sonra verilerin betimsel olarak incelenmesini içermektedir. Birincil araştırma, dahil edilme ve hariç tutulma kriterlerine göre bu meta-analiz çalışmasına dahil edilen araştırmalar için kullanılmaktadır.

\section{Veri toplama}

Bu çalışma için etik kurul izni 01.12.2020 tarih ve 12 sayılı Gazi Üniversitesi Ölçme ve Değerlendirme Etik Alt Çalışma Grubu'ndan alınmıştır. Fen eğitiminde hesaplamalı düşünmeyi konu edinen yapılmış bilimsel makale, yüksek lisans tezleri ve doktora tezleri bu çalışmanın birincil araştırmaları yani veri kaynağıdır.

Alan yazın tarama sürecinde türkçe kaynakları tararken "fen eğitimi, öğretimi ve fen öğrenme", "STEM" ve "hesaplamalı düşünme", "bilgisayarca düşünme", "bilgi işlemsel düşünme" ve "komputasyonel düşünme"; ingilizce kaynakları tararken ise "science education, science teaching, science learning, STEM ve computational thinking" ifadeleri anahtar kelime olarak kullanılmıştır. Ardından belirtilen anahtar kelimeler doğrultusunda gerçekleştirilen çalışmalar aşağıda belirtilen kriterler dikkat edilerek araştırmaya dahil edilmiştir.

\section{Dahil Edilme Kriterleri}

1. Fen eğitimine ilişkin uygulama veya değişkenler içermesi,

2. 2006 yllında Jeannette Wing'in "Computational Thinking" isimli makalesinin konuya ilişkin öncü yayın olarak kabul edilmesinden dolayı (Wing, 2006); 20062020 yılları arasında yayınlanmış olması,

3. Hesaplamalı düşünme becerisinin bağımlı değişken olması,

4. Yüksek lisans ve doktora tezleriyle (yayınlanmış yada yayınlanmamış), akademik (hakemli) dergilerdeki makaleler, kongre ve sempozyum bildirileri,

5. Deneysel ya da yarı deneysel çalışmalar,

6. Etki büyüklüklerini hesaplayabilmek için gerekli verinin bulunduğu çalışmalar, 
7. Türkçe veya İngilizce dillerinde yayınlanmış çalışmalar,

\section{Hariç Tutulma Kriterleri}

1. Hakemli olmayan dergilerde yayımlanan makaleler,

2. Aynı yazarın tezinde ortaya koyduğu verileri yayınladığı makaleye ulaşılmışsa, tez çalışması

3. Etki büyüklüğü değerini veya hesaplanmasını sağlayacak istatistiksel veriyi rapor etmeyen çalışmalar,

4. Dahil edilme kriterlerini sahip olmayan çalışmalar, araştırma kapsamı dışında tutulmuștur.

Kriterler doğrultusunda gerçekleşen veri tabanı tarama süreci Şekil-1 de gösterilmiştir. Anahtar kelimelerin aranmasıyla tespit edilen 112 araştırmadan 59 tanesi nitel araştırma olması, dört tanesi karma yönteme sahip olmasına rağmen hesaplamalı düşünme verisinin nitel olmasından dolayı araştırma kapsamı dışında kalmıştır. Ayrıca kalan 49 araştırmadan dört tanesi meta-analiz çalışması olması, bir tanesi ölçek geliştirme çalışması olması, beş tanesi tez-makale çalışması ve beş tanesi de etki büyüklügü hesaplamaya yarayacak istatistiksel verinin rapor edilmemesinden dolayı araştırma kapsamı dışında tutulmuştur.

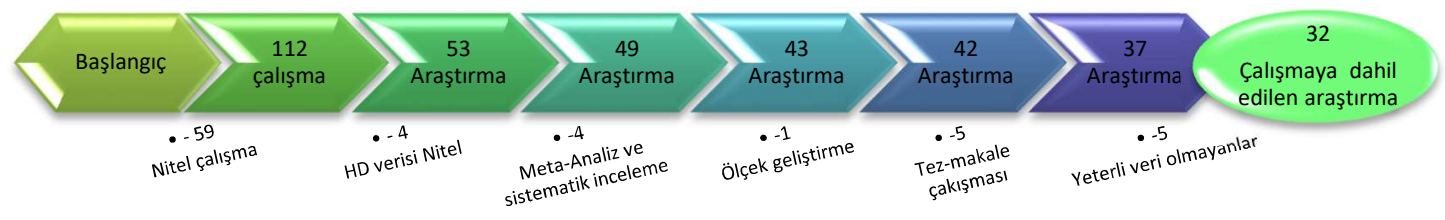

Şekil 1. Veri tabanı tarama süreci

\section{Kodlama yöntemi}

Bir meta-analiz çalışmasının veri toplama aracı, kodlama sayfasıdır (Üstün, 2012). Bu çalışmaya başlarken kodlama sayfası fen eğitiminde hesaplamalı düşünmeye ilişkin araştırmalar incelenerek hazırlanmıştır. Alan uzmanlarının görüşleri doğrultusunda değişiklikler yapılarak son şekli verilen kodlama sayfasıyla betimsel istatistik için birincil araștırma verileri hazırlanmıştır.

\section{Veri analizi}

Birincil araştırmalar verileri kodlama sayfasında yer alan değişkenler yönünden incelenmiş ve betimsel olarak analiz edilmiştir. Betimsel analiz, büyük hacimli verileri sayısal ve grafiksel yöntemleri kullanarak özetleme ve yoğunlaştırılması, başka bir ifadeyle verinin hacminin azaltılarak kullanılabilirliğini artırmayı amaçlar (Gürsakal ve Oğuzlar, 2015). 


\section{BULGULAR}

Araştırma da elde edilen bulgular, kullandıkları anahtar kelimeler, yayın türü, yıl, yayın dili, araştırma yöntemleri, örneklem özellikleri, kapsadığı konu alanı ve uygulamalar ve kullanılan ölçeğin özelliklerine göre aşağıdaki başlıklar altında incelenmiştir.

\section{Fen Eğitiminde Hesaplamalı Düşünme Araştırmalarında Kullanılan Anahtar kelimeler}

Araştırma kapsamında incelenen birincil araştırmalarda kullanılan anahtar kelimeler Şekil-2 ve Şekil-3 de kelime bulutu ile görselleștirilmiştir. Kelime bulutunda tekrarlanma sayısı fazla olan kelimeler daha büyük punto ile yer almaktadır. Farklı alanlarda gerçekleștirilen hesaplamalı düşünme çalışmalarının doğası gereği anahtar kelimelerin çeşitlilik gösterdiği ortaya çıkmıştır.

Türkçe olarak yayınlanan araştırmaların "Computational Thinking" ifadesinin Türkçe karş̧lığı olarak kullanılan bilgi işlemsel düşünme ( $f=3$ ), bilgisayarca düşünme ( $f=2)$, ifadelerinin yanı sıra bilimsel süreç becerileri $(f=1)$, fen başarısı $(f=1)$ ve diğer anahtar kelimelerin yalnızca birer araştırmada kullanıldığı görülmüştür.

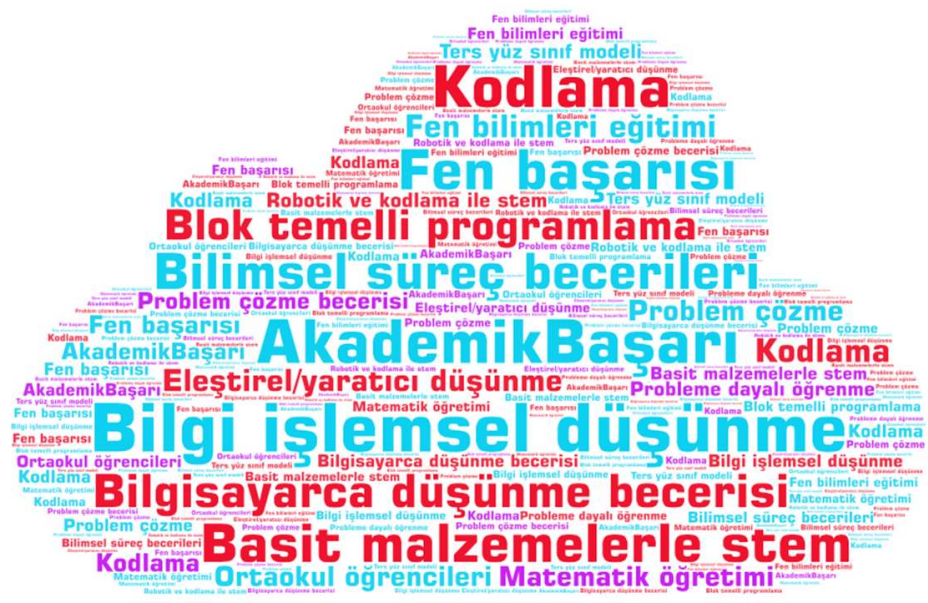

Şekil 2. Türkçe araştırmaların anahtar kelimeleri

$\mathrm{Bu}$ araştırma kapsamında incelenen birincil araştırmalardan İngilizce olarak sunulanlarında da Türkçe çalışmalarda olduğu gibi anahtar kelimeler bakımından çeşitlilik dikkat çekmektedir. İngilizce anahtar kelimelerin kullanım sıklıkları computational thinking $(\mathrm{f}=18)$, STEM $(\mathrm{f}=05)$, science education $(\mathrm{f}=4)$, ve Assessment, Robotics Science learning Self-efficacy $(\mathrm{f}=3$ ) olarak belirlenmiştir. Geriye kalan İngilizce anahtar kelimelerden beş tanesi ikişer araştırmada, 67 tanesi tanesi ise yalnızca birer araştırmada kullanılmıștır. 


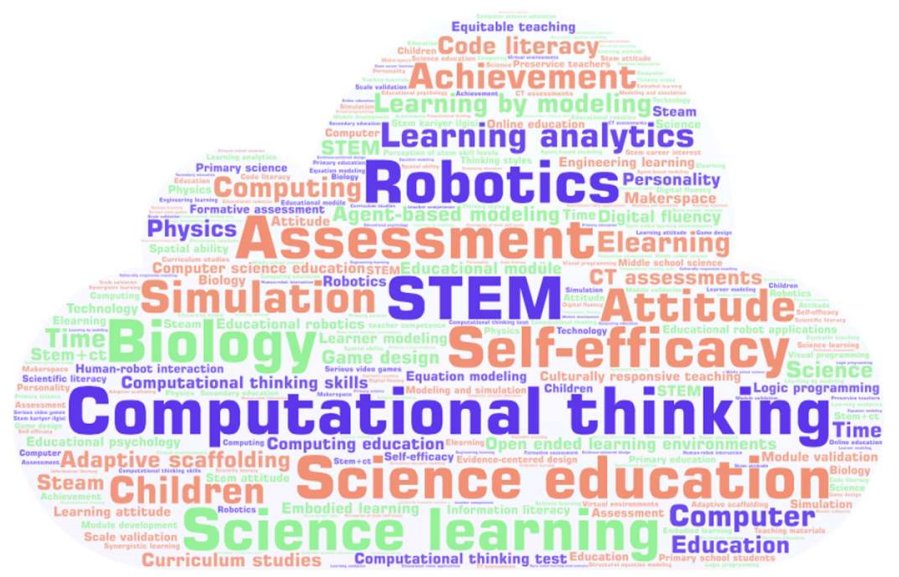

Şekil 3. İngilizce araştırmaların anahtar kelimeleri

\section{Fen Eğitiminde Hesaplamalı Düşünme Araştırmalarında Yayın Türü}

2006 -2021 (Mayıs ayı) yılları arasında fen eğitimi alanında ulusal ve uluslararası alan yazında hesaplamalı düşünmeye ilişkin yapılan araştırmalar incelendiğinde; \%69'unun hakemli akademik dergilerde makale, \%16'sının doktora tezi, \% 6'sının yüksek lisans tezi ve \%'9'unun kongre bildirisi olduğu görülmüştür.

\section{Tablo 1}

Fen Eğitiminde Hesaplamalı Düşünme Araştırmalarında Yayın Türü

\begin{tabular}{lll}
\hline & Frekans & $\%$ \\
Yayın Türü & & 69 \\
\hline Dergi makalesi & 22 & 6 \\
Yüksek Lisans Tezi & 2 & 16 \\
Doktora Tezi & 5 & 9 \\
Kongre Bildirisi & 3 & (16 \\
\hline
\end{tabular}

\section{Fen Eğitiminde Hesaplamalı Düşünme Araştırmalarında Yıl}

$\mathrm{Bu}$ çalışmaya dahil edilen birincil araştırmalar uygulamanın yapıldığı yıl, yayın için önerildiği yıl ve yayınlandığı yıl bakımından incelenmiştir. Uygulamanın yapıldığı yılı belirtmemiş araştırmaların \%41, yayın için önerildiği yıl belirtilmemiş araştırmaların ise \%47 oranında olması dikkat çekicidir. Tablo 2 incelendiğinde ise araştırmaların \%85'inin 2018 yılından sonra yayınlanmış olduğu görülmektedir. 
Tablo 2

Fen Eğitiminde Hesaplamalı Düşünme Araştırmalarında Yıl

\begin{tabular}{lcccccc}
\hline & \multicolumn{2}{c}{$\begin{array}{c}\text { Uygulamanın yapıldığı } \\
\text { Yll }\end{array}$} & \multicolumn{2}{c}{$\begin{array}{c}\text { Yayın için önerildiği } \\
\text { Yıl }\end{array}$} & \multicolumn{2}{c}{ Yayınlandığı Yıl } \\
\hline Belirtilmemiş & Frekans & $\%$ & Frekans & $\%$ & Frekans & $\%$ \\
2021 & 13 & 41 & 15 & 47 & 0 & 0 \\
2020 & 0 & 0 & 0 & 0 & 3 & 9 \\
2019 & 1 & 3 & 8 & 25 & 12 & 38 \\
2018 & 5 & 16 & 4 & 13 & 4 & 13 \\
2017 & 4 & 13 & 1 & 3 & 8 & 25 \\
2016 & 3 & 9 & 1 & 3 & 3 & 9 \\
2015 & 3 & 9 & 3 & 9 & 0 & 0 \\
2014 & 2 & 6 & 15 & 0 & 2 & 6 \\
\hline
\end{tabular}

\section{Fen Eğitiminde Hesaplamalı Düşünme Araştırmalarında Yayın Dili ve Uygulamanın yapıldı̆̆ı ülke}

Tablo 3 incelendiğinde birincil araştırmaların \%16'sının Türkçe, \%84'ünün İngilizce olarak yayınlandığı görülmektedir. Tablo 3 incelendiği zaman birincil araştırmalardan \%34'ünün uygulamalarının Türkiye'de, \% 38'inin uygulamalarının da ABD'de yapıldığı, geri kalanlarınsa Endenozya da \%6, Yunanistan da \%6, Malezya da \%3, Çin de \%3, Kanada da \%3 ve İspanya da \%3 gerçekleştirildiği görülmektedir.

Tablo 3

Fen Eğitiminde Hesaplamalı Düşünme Araștırmalarında Yayın Dili ve Uygulamanın Yapıldığı Ülke

\begin{tabular}{lll}
\hline Yayın Dili & $\mathrm{f}$ & $\%$ \\
\hline Türkçe & 5 & 16 \\
İngilizce & 27 & 84 \\
\hline Uygulamanın yapıldığı ülke & & \\
\hline Belirtilmemiş & 1 & 34 \\
Türkiye & 11 & 38 \\
ABD & 12 & 6 \\
Endenozya & 2 & 6 \\
Yunanistan & 2 & \\
\hline
\end{tabular}




\begin{tabular}{lll}
\hline Malezya & 1 & 3 \\
Çin & 1 & 3 \\
Kanada & 1 & 3 \\
İspanya & 1 & 3 \\
\hline
\end{tabular}

\section{Fen Eğitiminde Hesaplamalı Düşünme Araştırmaların da Yöntem}

Birincil araştırmalarda bulunan yöntem başlığı altındaki "araştırmada pilot çalışma yapılma" durumu da incelenmiştir. Araştırmaların \%41'inde pilot çalışma yapıldığı, \%59'un da ise pilot çalışma yapılmadığı görülmüştür (Tablo 4). Araştırma yöntemi açısından incelendiğinde ise birincil araştırmaların \%38'nin Nicel, \%63'ünün ise karma yönteme göre planlandığı ancak hesaplamalı düşünmeye ilişkin verisinin nicel yöntemlerle toplandığı olduğu tespit edilmiştir. Tablo 4'te araştırma deseni yarı deneysel olan araştırmaların \%56, zayıf deneysel olanların \%19 ve deneysel olanların \%6 oranında olduğu görülmektedir.

Tablo 4

Fen Eğitiminde Hesaplamalı Düşünme Araştırmalarında Yöntem

\begin{tabular}{lll}
\hline Araştırmada pilot çalışma yapılmış mı? & f & yüzde \\
\hline Evet & 13 & 41 \\
Hayır & 19 & 59 \\
\hline Araştırmanın Yöntemi & & 38 \\
\hline Nicel Yöntem & 12 & 63 \\
Karma Yöntem & 20 & \\
\hline Araştrmanın Deseni & & 3 \\
\hline Belirtilmemiş & 1 & 6 \\
Gerçek Deneysel Desen & 2 & 56 \\
Yarı Deneysel Desen & 18 & 19 \\
Zayıf Deneysel Desen & 6 & 16 \\
Deneysel Olmayan Desen & 5 & 0 \\
\hline Araştırma Modeli & & 38 \\
\hline Belirtilmemiş & 0 & 3 \\
Deney-kontrol gruplu ön test/ son test modeli & 12 & 34 \\
Deney-kontrol gruplu son test modeli & 1 & 9 \\
Tek grup ön test/son test modeli & 11 & 16 \\
Tek grup son test modeli & 3 & \\
İlişkisel tarama modeli & 5 & \\
\hline
\end{tabular}

\section{Fen Eğitiminde Hesaplamalı Düşünme Araştırmaların da Örneklem}

Birincil araştırmaların örneklemleri örnekleme yöntemi, okul seviyesi, demografik yapı ve okul türü bakımından değerlendirilmiştir. Örnekleme yöntemini belirtmeyen araştırmaların oranı \%9'dur. Araştırmaların çoğunluğunun (\%47) kullanışlı rastgele 
olmayan örnekleme ve \%16'sının amaçlı rastgele olmayan örnekleme yöntemiyle örneklem belirlediğinin yanı sıra \%19'unun basit rastgele örnekleme yöntemini kullandığ 1

Tablo 5 de görülmektedir.

Örneklem grubunun okul seviyesi 5-8. Sınıf olan araştırmaların \%53, 9-12. Sınıf olanların $\% 22$ ve lisans düzeyindeki öğrenciler olan araştırmaların \%16 olarak tespit edilmiştir. İlgili frekans değerleri de

Tablo 5 de sunulmuştur. \%72 oranında kentsel ve \%16 oranında kırsal bölgede yapılan birincil araştırmaların \%9'unun örneklem demografisi hakkında bilgi vermediği de tespit edilmiştir.

Tablo 5

Fen Eğitiminde Hesaplamalı Düşünme Araștırmaların da Örneklem

\begin{tabular}{lll}
\hline Örnekleme Yöntemi & f & $\%$ \\
\hline Belirtilmemiş & 3 & 9 \\
Basit Rastgele Örnekleme & 6 & 19 \\
Tabakalı Rastgele Örnekleme & 0 & 0 \\
Küme Rastgele Örnekleme & 1 & 3 \\
İki aşamalı Rastgele Örnekleme & 1 & 3 \\
Sistematik Rastgele Olmayan Örnekleme & 1 & 3 \\
Kullanışlı Rastgele Olmayan Örnekleme & 15 & 47 \\
Amaçlı Rastgele Olmayan Örnekleme & 5 & 16 \\
\hline Örneklem Grubu(Okul Seviyesi) & & 0 \\
\hline Belirtilmemiş & 0 & 0 \\
1-4. Sınıf & 0 & 53 \\
5-8. Sınıf & 17 & 22 \\
9-12. Sınıf & 7 & 16 \\
Lisans & 5 & 0 \\
Lisans Üstü & 0 & 6 \\
Öğretmenler & 2 & 3 \\
Karma & 1 & 9 \\
\hline Örneklem Demografik Yapısı & & 72 \\
\hline Belirtilmemiş & 3 & 16 \\
Kentsel & 23 & 3 \\
Kırsal & 5 & 69 \\
Karma & 1 & 9 \\
\hline Okul Türü & 3 & \\
\hline Belirtilmemiş & 2 & \\
Özel Okul & 22 & \\
Devlet Okulu & 3 & \\
Yaz Okulu & & \\
\hline
\end{tabular}


Örneklem özellikleri bakımından araştırmalar incelendiğinde, \%69'unun örneklemini devlet okullarında, \%6'sının özel okullarda öğrenim gören öğrencilerle gerçekleștirildiği ortaya çıkmıştır. Araştırmaların \%9'un da ise okul türü belirtilmemiştir.

\section{Fen Eğitiminde Hesaplamalı Düşünme Araştırmaların da Konu Alanı}

Tablo 6 incelendiğinde fen eğitiminde hesaplamalı düşünme ile ilgili araştırmaların \%47’sinin STEM, \%16 fen bilgisi, \%16 Fizik alanına ilişkin derslerde gerçekleștirildiği görülmektedir. Kimya alanındaki konularda hesaplamalı düşünme araştırmalarının \%3 gibi düşük bir oranda olması da önemli bir bulgudur.

Tablo 6

Fen Eğitiminde Hesaplamalı Düşünme Araştırmaların da Konu Alanı

\begin{tabular}{lll}
\hline Araştırmadaki Uygulamanın Konu Alanı & Frekans & $\%$ \\
\hline Belirtilmemiş & 2 & 6 \\
STEM & 15 & 47 \\
Fen Bilgisi & 5 & 16 \\
Fizik & 5 & 16 \\
Biyoloji & 3 & 9 \\
Kimya & 1 & 3 \\
Astronomi & 1 & 3 \\
\hline
\end{tabular}

\section{Fen Eğitiminde Hesaplamalı Düşünme Araştırmalarında Uygulamayla ilgili konular \\ Uygulama Süresi}

Deneysel ya da yarı deneysel bir araştırmada uygulamanın hangi sıklıkta ve uzunlukta yapıldığı önemli olduğundan süresinin ne kadar ayrıntılı verildiği de önem taşımaktadır. Uygulamayla ilgili bulguların sunulduğu Tablo 7'de uygulama süresini dakika olarak belirtenlerin \%34, hafta olarak belirtenlerin \%28 oranında olduğu ve süre bildirmeyenlerin oranının \%38 olduğu görülmektedir. Uygulama süresini hafta olarak belirtmiş olanların \%19'un da 1-3 hafta, \%27'sin de 4-7 hafta, \%13'ün de ise 12 haftadan daha uzun süre uygulama yapıldığı belirlenmiştir.

\section{Uygulamayı yapan kişi}

Birincil araştırmaların \%53'ünde uygulamayı hem deney hem de kontrol grubun da öğretmenin, \%22'sinde ise araştırmacının yaptığı ve \%25'inde ise uygulamayı yapan kişi bilgilerinin belirtilmediği Tablo 7 de görülmektedir.

\section{Uygulamada kullanılan araç}


Araştırma kapsamına dahil edilen çalışmaların uygulamalarının \%56'sında bilgisayar kullanıldığı, araştırmaların tamamının \%53'ünde kodlama, \%28'inde robotik, \%6'sında algoritma ve yine araştırmaların tamamını \%3'ünde ters yüz sınıf uygulamasının yapıldığı belirlenmiştir.

\section{Tablo 7}

Fen Eğitiminde Hesaplamalı Düşünme Araştırmalarında Uygulamayla ilgili bulgular

\begin{tabular}{|c|c|c|}
\hline \multicolumn{3}{|l|}{ Uygulama Süresi birimi } \\
\hline Belirtilmemiş & 12 & 38 \\
\hline Uygulama süresi dakika olarak belirtenler & 11 & 34 \\
\hline Uygulama süresini hafta olarak belirtenler & 9 & 28 \\
\hline \multicolumn{3}{|l|}{ Uygulama Süresi (Hafta) } \\
\hline Belirtilmemiș & 12 & 38 \\
\hline $1-3$ & 6 & 19 \\
\hline $4-7$ & 8 & 25 \\
\hline $8-11$ & 2 & 6 \\
\hline 12 ve üzeri & 4 & 13 \\
\hline \multicolumn{3}{|l|}{ Uygulayıcı kim? } \\
\hline Belirtilmemiș & 8 & 25 \\
\hline Deney Kontrol Araștırmacı & 7 & 22 \\
\hline Deney Kontrol Öğretmen & 17 & 53 \\
\hline \multicolumn{3}{|l|}{ Bilgisayar Kullanılmış mı? } \\
\hline Belirtilmemiș & 6 & 19 \\
\hline Evet & 18 & 56 \\
\hline Hayır & 8 & 25 \\
\hline \multicolumn{3}{|l|}{ Kodlama Kullanılmıș mı? } \\
\hline Belirtilmemiş & 6 & 19 \\
\hline Evet & 17 & 53 \\
\hline Hayır & 9 & 28 \\
\hline \multicolumn{3}{|l|}{ Robotik Kullanılmıș mı? } \\
\hline Belirtilmemiş & 6 & 19 \\
\hline Evet & 9 & 28 \\
\hline Hayır & 17 & 53 \\
\hline \multicolumn{3}{|l|}{ Algoritma Kullanılmıș mı? } \\
\hline Belirtilmemiş & 6 & 19 \\
\hline Evet & 2 & 6 \\
\hline Hayır & 24 & 75 \\
\hline \multicolumn{3}{|l|}{ Ters-Yüz Sınıf Uygulaması Kullanılmıș mı? } \\
\hline Belirtilmemiş & 6 & 19 \\
\hline Evet & 1 & 3 \\
\hline Hayır & 25 & 78 \\
\hline \multicolumn{3}{|l|}{ Uygulanan ișlem } \\
\hline Etkinlik Geliştirilmiş & 8 & 25 \\
\hline
\end{tabular}


Bilgi ve İletişim teknolojileri kullanılmış

$\begin{array}{ll}8 & 25 \\ 5 & 16 \\ 3 & 9 \\ 8 & 25\end{array}$

Yöntem karșılaștırması yapılmıs

16

İşlem uygulanmamış

25

Tablo 7 de görüldügü üzere birincil araştırmaların $\% 25$ 'inde hesaplamalı düşünmeyi geliştirmeye yönelik etkinlik geliştirilmiştir. Bilgi ve iletişim teknolojilerini kullanarak hesaplamalı düşünmeyi geliştirmeyi hedefleyen uygulama oranı $\% 25$, STEM uygulamalarıyla hesaplamalı düşünmeyi geliştirmeyi hedefleyen uygulama oranı \%16'dır. Uygulamada iki grup arasında yöntem karşılaştırması yapan araştırmaların oranınınsa \%9 olduğu görülmektedir.

\section{Fen Eğitiminde Hesaplamalı Düşünme Araştırmaların da Ölçek}

Fen eğitiminde hesaplamalı düşünme araştırmalarının tam yarısında Likert tipi ölçek, \%25'inde ise başarı testi kullanıldığı, \%6'sında ise kullanılan ölçeğin belirtilmediği

Tablo 8 de görülmektedir. Alan yazında kişilik özelliklerinin ölçülmesinde kullanılması tavsiye edilen Q sort (açık uçlu soru) (Block, 1964; Evelina ve Nadia, 2014) uygulamasının azlığı da dikkat çekicidir. Birincil araştırmalar da kullanılan ölçeğin geliştiricisinin kim olduğuna bakıldığından \%47'sinde araştırmacının kendisi tarafından geliştirilen ölçek ve yine \%47'sinde önceden var olan ölçek kullanıldığı, \%3'ün de ise kullanılan ölçeğin kim tarafından geliştirildiğinin belirtilmediği görülmüştür.

Tablo 8

Fen Eğitiminde Hesaplamalı Düşünme Araştırmalarında Ölçek

f $\%$

Kullanılan Ölçeğin türü:

\begin{tabular}{lll}
\hline Belirtilmemiş & 2 & 6 \\
Başarı Testi & 8 & 25 \\
Likert Tipi & 16 & 50 \\
Dereceli puanlama anahtarı & 2 & 6 \\
Q Sort (AçıUçlu Sorular) & 3 & 9 \\
Osgood'un Anlamsal Ayrım Ölçeği & 1 & 3 \\
\hline Ölçeğin Geliştiricisi: & & \\
\hline Belirtilmemiş & 1 & 3 \\
Önceden var olan ölçek & 15 & 47 \\
Araştırmacı tarafından geliştirilen & 15 & 47 \\
Uyarlanmış ölçek & 1 & 3
\end{tabular}




\section{SONUÇ, TARTIŞMA VE ÖNERİLER}

$\mathrm{Bu}$ çalışma fen eğitimi alanında hesaplamalı düşünme üzerine yapılmış çalışmaları bütüncül bir yaklaşımla betimsel olarak incelemektir. Doküman incelemesi yoluyla ulusal ve uluslararası veri tabanları incelenerek dahil edilme ve hariç tutulma kriterlerine uygun olduğu belirlenen birincil araștırmalar, anahtar kelimeler, yayın türü, yıl, yayın dili, araştırma yöntemleri, örneklem özellikleri, konu alanı ve uygulamalar ve veri toplama araçlarının özelliklerine göre değerlendirilmiştir. 32 birincil araştırmadan elde edilen bulgular dokuz alt başlıkta incelenmiştir.

Fen eğitiminde hesaplamalı düşünme araştırmaları yıl bazında incelendiği \%75' inin 2018 yılından sonra hatta \%38'inin 2020 yılında yayınlanmıştır (Tablo 2). Alan yazın incelemesi aşamasında hesaplamalı düşünme becerisinin çoğunlukla bilgisayar ve öğretim teknolojileriyle ilgili alanlarla ve matematikle ilişkilendirildiği görülmüştür. Fen bilimleri eğitiminde hesaplamalı düşünme çalışmalarının bu araştırma için başlangıç kabul edilen Wing (2006)'dan sonraki yıllarda giderek atış gösterdiği de görülmüştür. Bu araştırmada Türkçe karşılığı olarak hesaplamalı düşünme kullanılan "computational thinking” bir bilgisayar bilimcisi gibi düşünmeyi ifade eder ki bu ifade bilgisayarda programlama yapabilmekten çok fazlasını barındırmaktadır (Wing, 2006). Hesaplamalı düşünmenin özünde programlamayla birlikte programladıklarını zihinsel olarak yürütebilmek yer alır (Bocconi vd., 2016). Bu doğrultuda hesaplamalı düşünme becerisinin bir düşünme süreci olduğu ve problem çözmenin de bu sürecin bir parçası olduğu düşünüldüğünde fen bilimleriyle ilgili konularında onu geliştirmeye hizmet edebileceği göz ardı edilmemelidir.

Birincil araştırmaların tamamının \%16'sının Türkçe yayınlanmış olmasına karşın \%34'ünün Türkiye de yapılmış olması, ülkemizde fen eğitiminde hesaplamalı düşünmenin geliştirilmesine yönelik çalışmalara önem verildiği ortaya çıkmaktadır.

Eğer araştırma deneysel desenin tüm özelliklerine uygun planlanmazsa iç ve dış geçerlik sorunu yaşanabilir ve bunun sonucunda bulgular tartışmalı hale gelebilir (Yılmaz ve Tuncer, 2020). Bu risk uygulama öncesinde pilot çalışma yaparak ortadan kaldırılabilir. Ancak bu araştırma kapsamında incelen çalışmaların \%51'inde pilot çalışma yapılmadığı görülmektedir. Alan yazına araştırma konusu ile kalıcı ve doğru katkılar sağlamak için araştırmalar da pilot çalışma yapılmalıdır.

Bir araştırmacı ilgi alanındaki bir konuya ilişkin çözülmesi gereken bir problemi belirledikten sonra bu problemin çözümüne yönelik bir yöntem seçmelidir. Bu yöntem araştırmacının özelliklerine, araştırmanın amacına ve çözüm aranan problemin doğasına uygun olmalıdır (Creswell ve Creswell, 2018). Bu bağlamda birincil araştırmalar incelendiğinde \%37'sinin nicel yönteme uygun gerçekleştirildiği görülmektedir. Ancak nitel verilerle nicel verilerin birbirini desteklediği karma yöntem araştırmalarının daha çok ve nitelikli bilgi sağlayacağı düşünüldüğünde bu oranın önemi de görülmektedir. Araştırma yöntemi ve problemine uygun bir örneklem belirlenmesi doğru sonuçlara ulaşmak için önemlidir çünkü yanlış örneklem seçimi sonuçların geçerliliğini yitirmesine neden olur. $\mathrm{Bu}$ araştırmaya dahil edilen çalışmaların sadece \%19'unun basit rastgele 
örnekleme yöntemiyle örneklem belirmiş olması fen eğitiminde hesaplamalı düşünme araştırmalarının bulgularının geçerliliğiyle ilgili kaygı oluşturabilir. Diğer taraftan örneklem okul seviyesinin \%53 oranın da 5-8. sınıf seviyesinde olması sonuçların geçerliliği açısından başka bir tehdittir. Hesaplamalı düşünme 2018 yılında yayınlanan fen bilimleri dersi öğretim programın da beşinci ve altıncı sınıflar da bir ünite olarak yer almaktadır (MEB, 2018). Hesaplamalı düşünmenin "hesaplama" fiilinden oluşmadığı ve sadece matematik yada bilgisayar bilimine ilişkin bir düşünme süreci olmadığı dikkate alınmalı. Bu bağlamda okul öncesi, ilkokul ve ortaokulun tüm derslerinin öğretim programların da bir konu ya da ünite olarak değil bir hedef olarak yer alması bir ihtiyaçtır.

Yapılacak yeni araştırmalarda diğer eğitim basamaklarında da araştırmalar planlanması bu tehtidi ortadan kaldıracaktır. Aynı durum örneklemin demografik yapısıyla ilgili de söz konusudur. Birincil araştırmaların \%72' si kentsel bölgelerde gerçekleştirilmiştir. Dolayısıyla sonuçlarının genellenebilirliği mümkün değildir.

Bulgulara konu alanı açısından bakıldığında, dahil etme ve hariç tutma kriterlerine göre belirlenmiş araştırmalar da çoğunlukla STEM uygulamaları, fizik ve fen bilimleri konuları tercih edilmiştir. Ancak kimya, biyoloji ve astronomi alanları da hesaplamalı düşünme becerisinin geliştirilmesine uygun konular içermektedir. Öğrenen bireylerin ilgi alanları ve öğrenme stillerinin farklılık gösterdiğini dikkate alındığın da her alanda uygulamaların ișe koşulması gerekmektedir.

Bir deneysel çalışmada uygulamanın süresini belirlemeye yönelik kesin bir kural yoktur ancak süre bağımlı değişkende kalıcı değişim sağlamaya yetecek kadar uzun olmalı ancak; bağımlı değişkeni manipüle edebilecek başka faktörlerin etkin olmadığından emin olunmalı. Alan yazında yapılan meta analiz çalışmaların da deneysel uygulama yapılmasının süresi ne düzeyde olursa olursun araştırmanın etki düzeyinin yüksek- orta ve geniş düzeyde olduğu ancak süre belirli bir düzeyin üstüne çıkarsa etki büyüklüğünde düşüş olduğu görülmüştür (Balemen, 2016; Dağyar ve Demirel, 2015; Ural, 2014). Bu yüzden pilot çalışma yardımıyla uygulama için optimum sürenin belirlenmesi ve sürenin ayrıntılı bir şekilde araştırma raporunda belirtilmesi gerekmektedir.

Hesaplamalı düşünmeyi geliştirmeye yönelik araştırmalarda çoğunlukla bilgisayar, kodlama, robotik ve ters yüz sınıf yöntemi uygulamalarının kullanıldığı görülmüştür (Çakır ve Yaman 2018; Jaipal-Jamani ve Angeli 2017; Uşengül ve Bahçeci 2020). Günümüzde ters-yüz sınıf uygulamaların da hesaplamalı düşünme kapsamındaki becerilerin geliştirilmesine destek olacak materyallerin sıklıkla kullanıldığı görülmektedir (Çakır ve Yaman, 2018; Çukurbaşı ve Kıyıcı, 2018; Hamutoglu, 2021; Özüdoğru, 2018; Uşengül, 2019). Ancak hesaplamalı düşünme becerisinin kapsamında algoritmik düşünmenin de bulunduğunu unutmamak gerekmektedir. Algoritma etkinliklerinin kullanıldığı uygulama oranı \%6'dır. Hesaplamalı düşünme becerisini geliştirmenin hedeflendiği araştırmalarda algoritma ve kodlama etkinlikleri, bilgisayar kullanmadan da gerçekleştirilen uygulamalar planlanmalıdır. Birincil araştırmalarda kullanılan ölçeklere bakıldığında yapılan uygulamaya ilişkin olarak geliștirildiği 
görülmüştür. Güvenilirliği genellenebilir bir ölçek kullanılmaması araştırmaların sonuçlarının güvenilirliğini ve geçerliliğini de tehlikeye atma ktadır.

Fen eğitimi alanına hesaplamalı düşünmeyi geliştirmeye yönelik, alanın tüm alt dallarının dikkate alındığı, optimum sürenin pilot çalışmayla belirlendiği, araştırma yöntem-desen-modelinin probleme uygun belirlendiği araştırmalar planlanmalı.

\section{Kaynaklar}

AAAS (1990). American Association for the Advancement of Science. Science for All Americans: $\quad$ Education for a changing future. http://www.project2061.org/publications/sfaa/online/sfaatoc.htm adresinden erişilmiştir.

Aksit, 0. (2018). Enhancing Science Learning through Computational Thinking and Modeling in Middle School Classrooms: A Mixed Methods Study. North Carolina State University.

APA. (2020). Publication Manual of The American Psychological Association 7th. Washington DC.

Arthur, J., Bennett, W. ve Huffcutt, A. I. (2001). Conducting meta-analysis using SAS. Psychology Press.

Balemen, N. (2016). Proje tabanlı öğrenme yaklaşımının fen eğitimindeki etkililiği: meta analiz çalışması. (Yayımlanmamış Doktora Tezi) Gazi Üniversitesi, Eğitim Bilimleri Enstitüsü Ankara.

Basu, S. (2016). Fostering synergistic learning of computational thinking and middle school science in computer-based intelligent learning environments. (Unpublished Dissertation) Vanderbilt University.

Block, J. (1964). The Q-sort method in personality assessment and psychiatric research. The Journal of Nervous and Mental Disease, 136(6), 604-605.

Bocconi, S., Chioccariello, A., Dettori, G., Ferrari, A. ve Engelhardt, K. (2016). Developing computational thinking in compulsory education-Implications for policy and practice (No. JRC104188). Joint Research Centre (Seville site).

Çakir, E. ve Yaman, S. (2018). Ters Yüz Sınıf Modelinin Öğrencilerin Fen Başarısı ve Bilgisayarca Düşünme Becerileri Üzerine Etkisi.Gazi University Journal of Gazi Educational Faculty (GUJGEF), 38(1), 75-99.

Canbazoğlu Bilici, S., Küpeli, M. A., \& Guzey, S. S. (2021). Inspired by nature: an engineering design-based biomimicry activity. Science Activities, 58(2), 77-88.

Christensen, D. M. (2020). Learning Biological Evolution Through Computational Thinking (Doctoral dissertation) Temple University. 
Clark, D. (2015). Computational and algorithmic thinking, 2011-2015. Canberra, Australia: Australian Mathematics Trust.

Creswell, J. W. ve J. D. Creswell. (2018). Research Design Qualitative, Quantitative, and Mixed Methods Approaches. Los Angles/London/ New Delhi/Singapore/Washington DC/ Melbourne: SAGE.

Çukurbaşi, B. ve Kiyici, M. (2018). Öğretmen adaylarının elektronik portfolyoya yönelik görüşlerinin incelenmesi: Weebly örneği. İnönü Üniversitesi Eğitim Fakültesi Dergisi, 19(1), 1-14.

Dagyar, M. ve Demirel, M. (2015). Effects of problem-based learning on academic achievement: A meta-analysis study. Egitim ve Bilim, 40(181), 139-174.

Denning, P. J. (2017). Computational thinking in science. American Scientist, 105(1), $13-$ 17.

Ellis, P. D. (2010). The Essential Guide to Effect Sizes. Cambridge University Press.

Evelina, B. C. ve Nadia, B. C. (2014). The Q-sort technique used in identifying the level of methodological skills of the prospective teachers. Procedia-Social and Behavioral Sciences, 128, 60-65.

Glass, G. V. (1976). Primary, secondary, and meta-analysis of research. Educational researcher, 5(10), 3-8.

Gülbahar, Y., Çakıroğlu, Ü., Kalelioğlu, F., Delen, İ., Yıldız, B. ve Sayın, Z. (2020). Bilgi İşlemsel Düşünme Becerisinin Disiplinlerarası Yaklaşım ile Öğretimi. S. Akbıyık ve V. H. Kaya (Ed.). Ankara: MEB ÖYGM.

Gürsakal, N. ve Oğuzlar, A. (2015). No Title. Dora Yayıncılık.

Hamutoglu, N. B. (2021). A Road Map for the COVID-19 Pandemic Process to Ensure Quality of Assurance Active Learning Strategies in Online Learning Environments: How to Plan, Implement, Evaluate, and Improve Learning Activities. In Handbook of Research on Emerging Pedagogies for the Future of Education: Trauma-Informed, Care, and Pandemic Pedagogy (ss. 101-126). IGI Global.

Riley, D. D., \& Hunt, K. A. (2014). Computational thinking for the modern problem solver. CRC press.

Jaipal-Jamani, K. ve Angeli, C. (2017). Effect of robotics on elementary preservice teachers' self-efficacy, science learning, and computational thinking. Journal of Science Education and Technology, 26(2), 175-192.

Kizilay, E., Yamak, H. ve Kavak, N. (2019). Motivation Scale for STEM Fields. Journal of Computer and Education Research, 7(14), 540-557.

Lei, H., Chiu, M. M., Li, F., Wang, X. ve Geng, Y. J. (2020). Computational thinking and academic achievement: A meta-analysis among students. Children and Youth Services Review, 118, 105439.

Lipsey, M. W. ve Wilson, D. (2001). Practical Meta Analysis Overview. Applied Social Research Methods Series. 
MEB. (2018). Fen Bilimleri Dersi Öğretim Programı (Illkokul ve Ortaokul 3, 4, 5, 6, 7 ve 8. Sinıflar). Ankara.

NRC. (2000). National Research Council. Inquiry and the National Science Education Standards: A Guide for Teaching and Learning. Washington: DC: The National Academies Press.

Ortiz, C. J. (2018). An Experimental Comparison of Student Motivation Between Two Computational Thinking-based Stem Activities: Vex-based Automation and Robotics and a Quadcopter Activity (Doctoral dissertation) Utah State University.

Özüdoğru, M. (2018). The effect of flipped learning on pre-service teachers' achievement and perceptions related to classroom environment. (Unpublished Dissertation) Middle East Technical University.

Rosenthal, R. ve DiMatteo, M. R. (2001). Meta-analysis: Recent developments in quantitative methods for literature reviews. Annual review of psychology, 52(1), 5982.

Sánchez-Meca, J. ve Marín-Martínez, F. (2010). Meta-analysis in psychological research. International Journal of Psychological Research, 3(1), 150-162.

Strawhacker, A. L. (2020). Biodesign Education in Early Childhood: A Design-Research Study of the Tangible Crispee Technology and Learning Intervention (Doctoral dissertation) Tufts University.

Ural, G. (2014). İlköğretimde Fen ve Teknoloji Öğretimi Üzerine Türkiye'de Yapılan Araştırmaların Meta Analizi (Yayımlanmamış Doktora Tezi) Ege Üniversitesi, Sosyal Bilimler Enstitüsü, İzmir.

Uşengül, L. ve Bahçeci, F. (2020). The Effect of Lego Wedo 2.0 Education on Academic Achievement and Attitudes and Computational Thinking Skills of Learners toward Science. World Journal of Education, 10(4), 83-93.

Uşengül, L. (2019). Lego Wedo 2.0 eğitiminin öğrenenlerin fen bilimlerine yönelik akademik başarı ve tutumları ile bilgi işlemsel düşünme becerilerine etkisi (Yayınlanmamış yüksek lisans tezi). Fırat Üniversitesi, Elazı̆̆.

Üstün, U. (2012). To what extent is problem-based learning effective as compared to traditional teaching in science education? A meta-analysis study. (Unpublished Dissertation) Middle East Technical University.

Weese, J. L. (2017). Bringing computational thinking to K-12 and higher education. (Unpublished Dissertation) Kansas State University.

Wing, J. M. (2006). Computational thinking. Communications of the ACM, 49(3), 33-35.

Yilmaz, Ö. ve Tuncer, M. (2020). Deneysel bir araştirmada pilot çalişmanin önemi: dale'in yaşanti konisine göre öğretimin akademik başariya etkisi. Electronic Journal of Education Sciences, 9(17), 89-96. 
$\mathrm{Bu}$ çalışma için etik kurul izni 01.12.2020 tarih ve 12 sayılı Gazi Üniversitesi Ölçme ve Değerlendirme Etik Alt Çalışma Grubu'ndan alınmıştır.

Araştırmacıların Makaleye Katkı Oranı Beyanı:

1. yazar katkı oranı: $\% 50$

2. yazar katkı oranı: $\% 50$

Çıkar Çatışması Beyanı:

Yok.

Finansal Destek veya Teşekkür Beyanı

$\mathrm{Bu}$ çalıșma için herhangi bir kurumdan finansal destek alınmamıștır. 